\title{
Biolistic transformation of Moroccan durum wheat varieties by using mature embryo-derived calli
}

\author{
Chaimae Senhaji - Fatima Gaboun - Rabha Abdelwahd - Ghizlane Diria $\cdot$ Sripada Udupa $\cdot$ Allal Douira $\cdot$ Driss Iraqi
}

Received: 20 November 2021 / Revised: 22 December 2021 / Accepted: 23 December 2021

(c) Korean Society for Plant Biotechnology

\begin{abstract}
Environmental stresses are estimated to have reduced global crop yields of wheat by $5.5 \%$. However, traditional approaches for the transfer of resistance to these stresses in wheat plants have yielded limited results. In this regard, genetic transformation has undoubtedly opened up new avenues to overcome crop losses due to various abiotic stresses. Particle bombardment has been successfully employed for obtaining transgenic wheat. However, most of these procedures employ immature embryos, which are not available throughout the year. Therefore, the present investigation utilized mature seeds as the starting material and used the calli raised from three Moroccan durum wheat varieties as the target tissue for genetic transformation by the biolistic approach. The pANIC-5E plasmid containing the SINA gene for drought and salinity tolerance was used for genetic transformation. To enhance the regeneration capacity and transformation efficiency of the tested genotypes, the study compared the effect of copper supplementation in the induction medium (up to $5 \mu \mathrm{M}$ ) with the standard MS medium. The results show that the genotypes displayed different sensitivities to $\mathrm{CuSO}_{4}$, indicating that the transformation efficiency was highly genotype-dependent. The integration
\end{abstract}

C. Senhaji $(\bowtie)$

Biotechnology Research Unit, Institut National de la Recherche Agronomique (INRA), B.P. 415, Rabat, Morocco

e-mail: chaimae.310@gmail.com

F. Gaboun · R. Abdelwahd · G. Diria $\cdot$ D. Iraqi

Biotechnology Research Unit, Institut National de la Recherche

Agronomique (INRA), B.P. 415, Rabat, Morocco

S. Udupa

ICARDA-INRA Cooperative Research Project, International

Center for Agricultural Research in the Dry Areas, B.P. 6299,

Rabat, Morocco

\section{A. Douira}

Laboratory of Botany, Biotechnology and Plant Protection,

Faculty of Sciences-University Ibn Tofail, University campus,

B.P. 133, 14000 Kénitra, Morocco of transgenes in the $T_{0}$ transformants was demonstrated by polymerase chain reaction (PCR) analysis of the obtained resistant plantlets with primers specific to the SINA gene. Among the three genotypes studied, 'Isly' showed the highest efficiency of $9.75 \%$, followed by 'Amria' with $1.25 \%$ and 'Chaoui' with $1 \%$.

Keywords Biolistic transformation, Copper sulphate, Durum wheat, Matures embryos, Plasmid pANIC-5E, SINA gene.

\begin{abstract}
Abbreviations ANalysis Of Variance (ANOVA), Cetyltrimethylammonium bromide (CTAB), General Linear Model (GLM), National Institute of Research for Agriculture (INRA), Least Significant Difference (LSD), Murashige and Skoog (MS), Phosphinothricin (PPT), Seven In Absentia (SINA).
\end{abstract}

\section{Introduction}

Wheat is one of the most important crops grown worldwide. It is the third largest cereal in terms of production in the world after rice and maize and the second most important in terms of calories after rice. It is the primary source of proteins in lowand middle-income countries (www.wheat.org). Environmental stresses, such as drought, salinity of soil, and extreme temperatures, have decreased its production by 20 to $30 \%$. Moreover, with such an increasing population expected to reach 9 billion by 2050, wheat production has to be increased by about 60 to $70 \%$ (www.wheat.org). There has been considerable work done to develop drought tolerant wheat through classical breeding. However, progresses made are slow and still not up to the mark. In this way, genetic engineering proved to be an important method towards improving stresses tolerance in wheat varieties.

The transformation efficiency is determined by two groups of factors: the genetic transformation procedure and the target tissue. First, out of the various DNA delivery methods, biolistic and Agrobacterium-mediated methods have played an impor- 
tant role in wheat transformation (Tao et al. 2011). Biolistic bombardment remains however the most widely used method for obtaining transgenic wheat plants since monocotyledons have shown natural resistance to Agrobacterium infection (Ziolkowski 2007) and the efficiency of the Agrobacteriummediated method is usually no higher than 1 to $5 \%$ (Pukhalskii et al. 1996; Wu et al. 2003). Second, an essential prerequisite for the production of transgenic plants is the availability of a highly regenerable target tissue. Several factors have been described to influence the response of wheat to tissue culture including composition of culture medium for callus induction and plant regeneration (Ekom et al. 2014; Greer et al. 2009), the explant types (Redha and Talaat 2008), and the genotype (Vendruscolo et al. 2008; le Roux et al. 2016).

Immature embryos have been the most widely used explants to genetically transform wheat (Shewry and Jones 2005; Vasil 2005; Xia et al. 2012). Yet, immature embryos are not available throughout the year; require controlled conditions for raising explant donor plants, and skilled personnel to isolate them at a suitable stage (Parmar et al. 2012). Unlike their immature counterpart, mature embryos are available in large quantity throughout the year, can easily be stored as dried seeds and showed a regeneration response comparable to that of immature embryos (Maddock 1985; Ozgens et al. 1996; Ozias-Akins and Vasil 1983). Thus, the present study will exclusively focus on mature embryos as starting explants for transformation.

As the culture media constituents influenced growth and morphogenesis of plant tissues, many authors have observed that elevated concentrations of copper increases the effectiveness of the formation of embryos and regeneration in monocotyledonous and dicotyledonous plants, including triticale (Purnhauser and Gyalai 1993), barley (Dahleen 1995) and wheat (Ghaemi et al. 1994; Purnhauser 1991; Purnhauser and Gyulai 1993; Sparks et al. 2014; Tahiliani and Kothari 2004). These results are not surprising given the essential role played by this micro-element in orchestrating a range of physiological and biochemical functions. Copper is a constituent of the protein component of several enzymes, mainly those participating in electron flow, catalyzing redox reactions in plant cells. Also, copper takes part in the processes of photosynthesis, respiration, carbohydrate biosynthesis and nitrogen metabolism (Lolkema 1985; Purnhauser and Gyulai 1993). It is then essential to study the effect of CuSO4 on plant regeneration efficiency for Moroccan wheat varieties, especially after bombardment stress.

Genotypes are known to greatly influence the applicability and efficiency of biolistic gene transfer (Ekom et al. 2014; Iser et al. 1999; Rasco-Gaunt et al. 2001; Ye et al. 2001).
Efficient transformation systems are usually well developed for a single responsive genotype and are typically not transferrable to alternative genotypes (Hardwood 2012). Hence, it is necessary to develop transformation system for Moroccan wheat cultivars that are well adapted to Moroccan environment.

In the present study, seven in Absentia gene (SINA) was selected for the genetic transformation of Moroccan durum wheat varieties, with the objective of developing transgenic plants with increased tolerance to water and salinity stress tolerance. The effects of copper supplementation in callus induction media on regeneration capacity and transformation efficiency of the SINA gene using wheat mature embryo as explant were studied.

\section{Materials and Methods}

Plant materials and culture conditions

The seeds of 'Amria', 'Chaoui' and 'Isly' varieties were provided by the Experimental Research Station of National Institute of Agronomic Research (INRA) at Marchouch, Morocco. Mature seeds were surface-sterilized by washing with $70 \%$ (v/v) ethanol solution for $3 \mathrm{~min}$, followed by a bath in $2.4 \%$ sodium hypochlorite solution with a drop of TWEEN $® 20$ detergent for $15 \mathrm{~min}$ with agitation. Seeds were then rinsed three times with sterilized distilled water (under laminar flow). The disinfected seeds were soaked in sterilized distilled water overnight until seeds got fully turgid, and embryos swelled and increased in size. Mature embryos were aseptically excised from the caryopses, the remaining endosperm and radical to prevent early germination. The embryos were then split and placed with the scutellum upwards on 2 induction media, IM1 or IM2. The medium IM1, as defined by (Murashige and Skoog 1962) and the modified medium IM2 with the same components as IM, supplemented with $1.25 \mathrm{mg} / \mathrm{l}$ of $\mathrm{CuSO}_{4}$. Both media were supplemented with 20 g/l sucrose, $2 \mathrm{mg} / 1$ picloram, $100 \mathrm{mg} / 1$ Myo-inositol, $150 \mathrm{mg} / 1$ $\mathrm{L}$-Asparagine and $2.5 \mathrm{~g} / \mathrm{l}$ phytagel. All media were adjusted to $\mathrm{pH}$ 5.8. Cultures were incubated at $25^{\circ} \mathrm{C}$ in darkness for approximately 3 to 4 days before bombardment.

The induction parameters were defined as follow:

$$
\text { PCIBB }=\frac{\text { Number of induced calli }}{\text { Total number of explants cultured }} \times 100
$$

$$
\text { PCIAB }=\frac{\text { Number of induced calli after bombardment }}{\text { Total number of bombarded calli }} \times 100
$$


Where: PCIBB- Percentage of callus induction before bombardment

PSCAB- Percentage of callus induction after bombardment

Bacteria materials and genetic construction

The plasmid used for bombardment is pANIC $-5 \mathrm{E}$ (Fig. 1), containing the linked selectable marker/herbicide resistance bar (phosphinothricin acetyl transferase) gene (placed under the transcriptional control of the rice actin 1 gene (OsAct1) promoter and the $35 \mathrm{~S}$ terminator). The vector was modified by cloning the SINA gene into the Gateway_ cassette by placing the SINA gene inserted between attR1 and attR2 recombination sites (Kindly provided by Mohamed Fokar).

The Escherichia coli strain carrying plasmid pANIC- 5E harboring SINA gene construct were grown over night in LB solid medium supplemented with $100 \mathrm{mg} / \mathrm{l}$ Ampicillin and 50 $\mathrm{mg} / \mathrm{l} \mathrm{Kanamycin} \mathrm{at} 37^{\circ} \mathrm{C}$. A single colony was subcultured in $5 \mathrm{ml} \mathrm{LB}$ liquid medium at $37^{\circ} \mathrm{C}$ for 2 days in a shaking incubator (set at $150 \mathrm{rpm}$ ), followed by the addition of $45 \mathrm{ml}$ of fresh LB liquid medium and a further growth for $5 \mathrm{~h}$. Plasmid DNA was isolated using the Bioline ISOLATE II Plasmid Mini Kit.
Particle bombardment, production and selection of transformants

Three to five days after placing the mature embryos on callus induction medium, induced embryos were placed in the center of a petri dish for 4 hours in the osmotic MS medium supplemented with $15 \%$ mannitol, and bombarded at 1,100 psi helium pressure, at a target distance of $9 \mathrm{~cm}$ and under a vacuum of $28 \mathrm{mmHg}$ with $1 \mu \mathrm{m}$ gold particles. The gold particles used for the bombardment were coated with the plasmid DNA (pANIC- 5E) containing the SINA gene as per the procedure described by Iraqi et al. (2005). The Biolistic PDS-1000/He system (Bio-Rad, USA) was used for the bombardment. Following bombardment, calli were first incubated in high osmotic medium for $16 \mathrm{~h}$, and then incubated in IM1 or IM2 induction medium for 4 weeks in the dark at $25^{\circ} \mathrm{C}$. The calli were then transferred to the regeneration medium supplemented with $1 \mathrm{mg} / \mathrm{l}$ of Zeatin and $3 \mathrm{mg} / \mathrm{l}$ of PPT (Phosphinothricin) for a period of 9 weeks at $25^{\circ} \mathrm{C}$, under $16 / 8 \mathrm{~h}$ light/dark cycle with a medium change every 3 weeks. The surviving regenerated plantlets were transferred for rooting to MS half-strength medium lacking hormones. The rooted plants showing resistance to PPT were transplanted into soil filled pots and grown in a green-house until maturity.

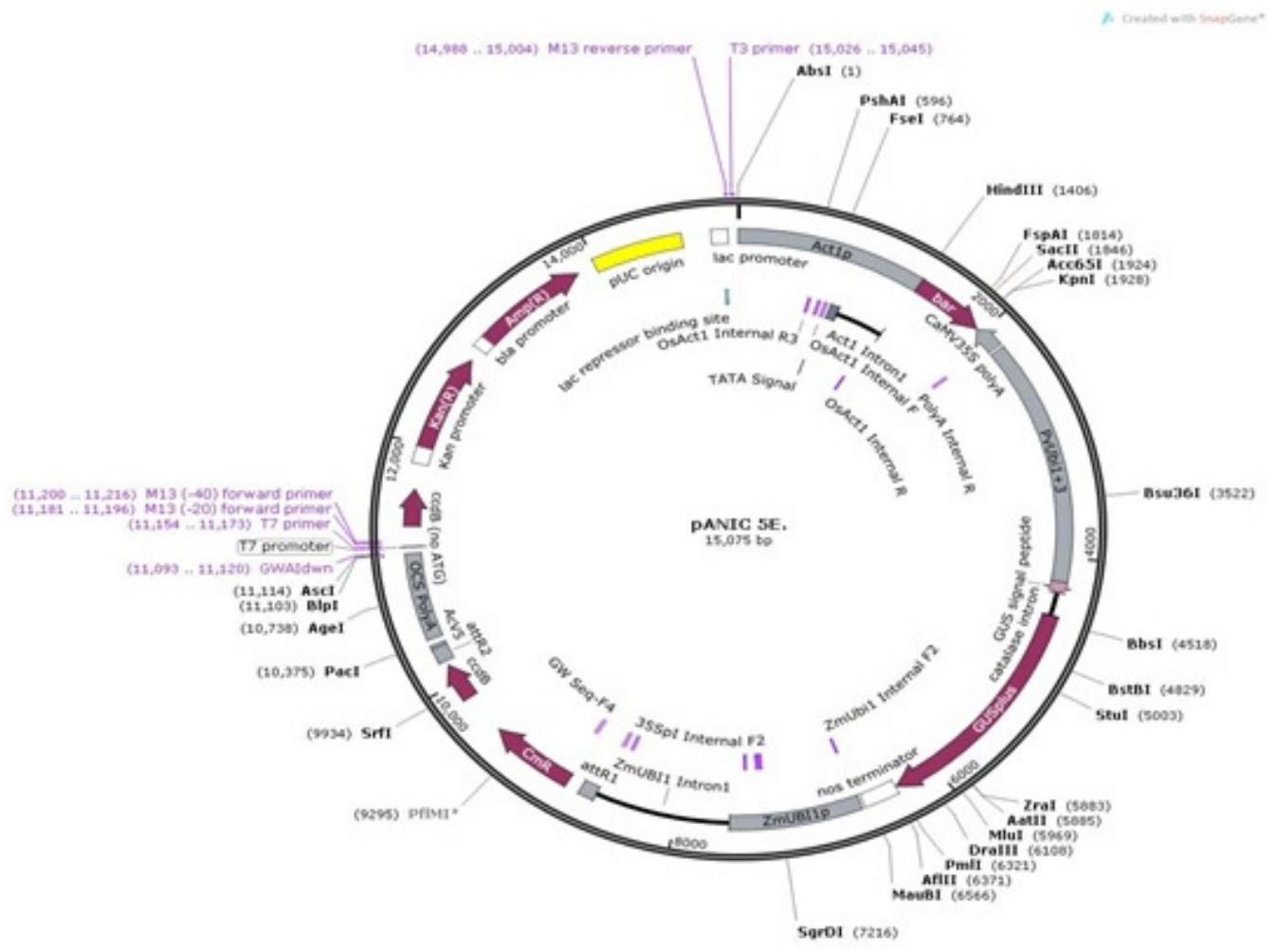

Fig. 1 Vector maps of pANIC-5E (created with snapGene) 
The regeneration parameters were defined as follow:

$\mathrm{PCR}=\frac{\text { Number of calli with regenerated seedlings }}{\text { Number of calli transferred to regeneration }} \times 100$

$\mathrm{PPR}=\frac{\text { Number of plantelets regenerated }}{\text { Number of calli transferred to regeneration }} \times 100$

$\mathrm{NPPRC}=\frac{\text { Number of regenerated plantelets }}{\text { Number of calli with regenerated seedlings }} \times 100$

Where: PCR- Percentage of callus regeneration

PPR- Percentage of plantlets regeneration

NPPRC- Number of plantlets per regenerating callus

The regeneration parameters were calculated for each genotype eight weeks after the transfer of callus into the regeneration medium.

Statistical analysis

The treatments consisted of 10 replications of for every medium and variety; each replication contained 20 explants (mature embryos). For the analysis of callus induction and resistant plantlets to selective agent phosphinothricin (PPT), Analysis of variance (ANOVA) was performed using the General Linear Model (GLM) procedure in SAS (SAS Institute 1985). Means of treatments were compared using the Least Significant Difference (LSD) test. Student's t-test was applied at a probability level of $p=0.05$ to find significant differences between the means.

Genomic DNA isolation and PCR analysis

The total genomic DNA was extracted from leaf material using a modified CTAB procedure (Udupa et al. 1998) for all the regenerated PPT resistant plantlets. PCR analysis of genomic DNA was carried out using 50 ng DNA template, $1 \mathrm{x}$ Taq DNA polymerase buffer, $200 \mu \mathrm{M}$ of each dNTP; $0.5 \mu \mathrm{M}$ of each primer, and 0.6 unit of Taq DNA polymerase (Promega) in a $20-\mu \mathrm{L}$ reaction volume. Primers pairs used for amplification of the SINA gene were F: 5'-ATGGAACCTCG AATCAATG -3' and R: 5'-TCATATCGAAACAGGCTGTTC $-3^{\prime}$. The PCR protocol was as follow: an initial denaturation at $95^{\circ} \mathrm{C}$ for $5 \mathrm{~min}, 35$ cycles of $94^{\circ} \mathrm{C}$ for $30 \mathrm{~s}, 59^{\circ} \mathrm{C}$ for $30 \mathrm{~s}, 72^{\circ} \mathrm{C}$ for $45 \mathrm{~s}$, and final extension at $72^{\circ} \mathrm{C}$ for $5 \mathrm{~min}$. The PCR products were run on a $1 \%$ agarose gel stained with ethidium bromide, and visualized with UV light (306 nm). The amplified transgene product size was compared with the positive control.

\section{Results}

Callus induction

The callus induction rate was assessed after 4 days of embryos culture before bombardment. Results show an important callus induction rate that varies between $89 \%$ and $93 \%$, without significant differences between genotypes (Table 1). There was no significant difference in the callus induction rate resulting from $\mathrm{CuSO}_{4}$ supplementation for 'Amria' and 'Isly' . The 'Chaoui' variety, however, showed significant drop in induction rate under $\mathrm{CuSO}_{4}$ rich medium IM2 (Fig. 2A). The rate of survived calli after bombardment did not differ significantly between genotypes, with a survival rate in excess of $95 \%$ for all three varieties (Table 1). Similarly, there was no significant effect of $\mathrm{CuSO}_{4}$ supplementation for all tested genotypes (Fig. 2B).

Table 1 Induction parameters for the three durum wheat varieties obtained on two induction media (IM1 and IM2) after 4 weeks of culture and their effects on callus regeneration, plantlet regeneration, and number of plantlets per regenerating callus

\begin{tabular}{|c|c|c|c|c|c|}
\hline Variety & $\begin{array}{l}\text { Callus induction } \\
\qquad(\%)\end{array}$ & $\begin{array}{c}\text { Callus survival } \\
\text { after bombardment } \\
(\%)\end{array}$ & $\begin{array}{c}\text { Callus regeneration } \\
(\%)\end{array}$ & $\begin{array}{l}\text { Plantlet regeneration } \\
\qquad(\%)\end{array}$ & $\begin{array}{l}\text { Number of } \\
\text { plantlets per } \\
\text { regenerating callus }\end{array}$ \\
\hline 'Amria' & $92.29 \mathrm{a}$ & $95.77 \mathrm{a}$ & $4.64 b$ & $21.26 \mathrm{~b}$ & $2.55 \mathrm{ab}$ \\
\hline 'Chaoui' & $89.79 \mathrm{a}$ & $98.76 a$ & $4.90 \mathrm{~b}$ & $17.42 \mathrm{~b}$ & $2.10 \mathrm{~b}$ \\
\hline 'Isly' & $93.75 \mathrm{a}$ & $99.07 \mathrm{a}$ & $14.48 \mathrm{a}$ & $53.71 \mathrm{a}$ & $4.08 \mathrm{a}$ \\
\hline LSD & 4.72 & 3.63 & 5.25 & 19.08 & 1.74 \\
\hline IM1 & $94.58 \mathrm{a}$ & $98.17 \mathrm{a}$ & $8.26 a$ & $30.16 a$ & $2.85 \mathrm{a}$ \\
\hline IM2 & $89.30 \mathrm{~b}$ & $97.56 \mathrm{a}$ & $7.76 \mathrm{a}$ & $31.43 \mathrm{a}$ & $2.97 \mathrm{a}$ \\
\hline LSD & 3.85 & 2.96 & 4.29 & 15.58 & 1.42 \\
\hline
\end{tabular}

Use of the same letter "a" or "b" indicates that the results are not significantly different at $a=0.05$ according to the Least Significant Difference (LSD) test. 

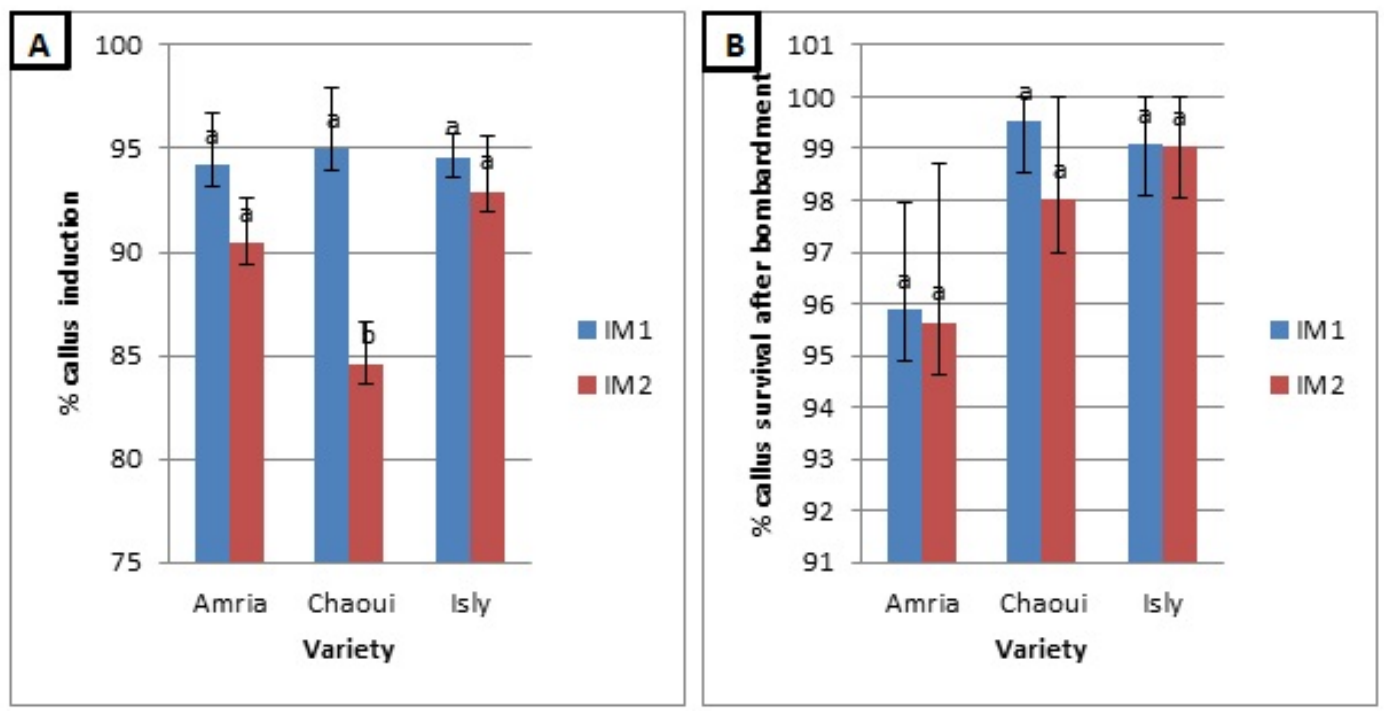

Fig. 2 Effect of the induction medium on callus induction (A) and percentage of surviving calli after bombardment (B) in mature embryos of the three durum wheat varieties after 4 weeks of culture. Use of the same letter "a" or "b" above the bar indicates that the results are not significantly different at $a=0.05$ according to the LSD test
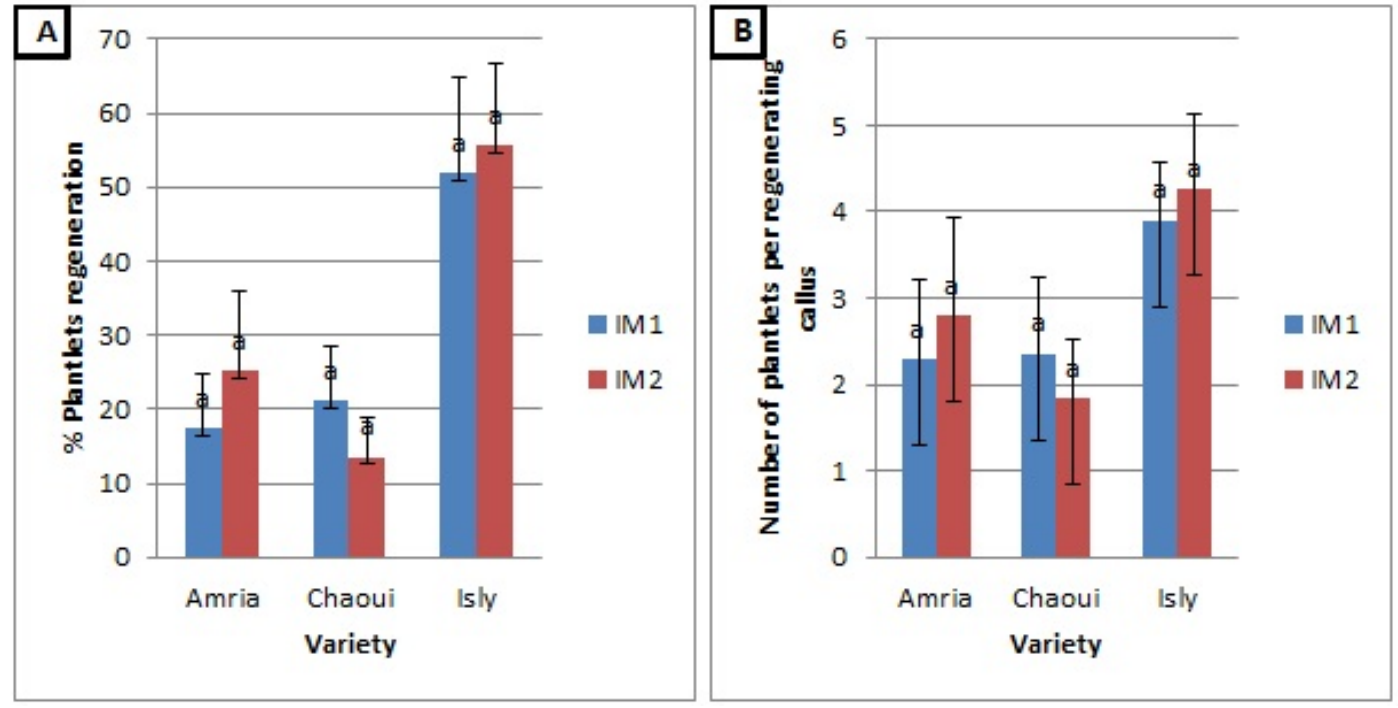

Fig. 3 Effect of induction medium on the plantlet regeneration percentage (A) and the number of plantlets per regenerating callus (B) for mature embryos of the three durum wheat varieties. Use of the same letter "a" or "b" above the bar indicates that the results are not significantly different at $a=0.05$ according to the LSD test

\section{Plant regeneration}

For the 'Amria' and 'Isly' varieties, higher concentration of $\mathrm{CuSO}_{4}$ in the induction medium enhanced the rate of plantlets regeneration by about $8 \%$ and $4 \%$ respectively. For the 'Chaoui' variety, higher concentration of $\mathrm{CuSO}_{4}$ in the medium IM2 reduced the rate of plantlets regenerated by about $8 \%$. Although the results were not statistically significant between induction media in terms of plantlets regeneration parameters (Fig. 3), the differences were significant between genotypes in all studied regeneration parameters. The 'Isly' variety showed the highest regeneration capacity (Table 1).

$\mathrm{CuSO}_{4}$ supplementation and transformation efficiencies

To confirm the presence of SINA gene in the transgenic plants $\mathrm{T} 0$, all the independent putative transformants generated were analyzed by PCR amplification of genomic DNA using primers specific to SINA gene. Transformation efficiency was calculated as the number of transgenic plants obtained (plants surviving PPT-selection and PCR-positive for the SINA gene) per number of bombarded embryos $\times 100$ (Pastori et al. 2001; 


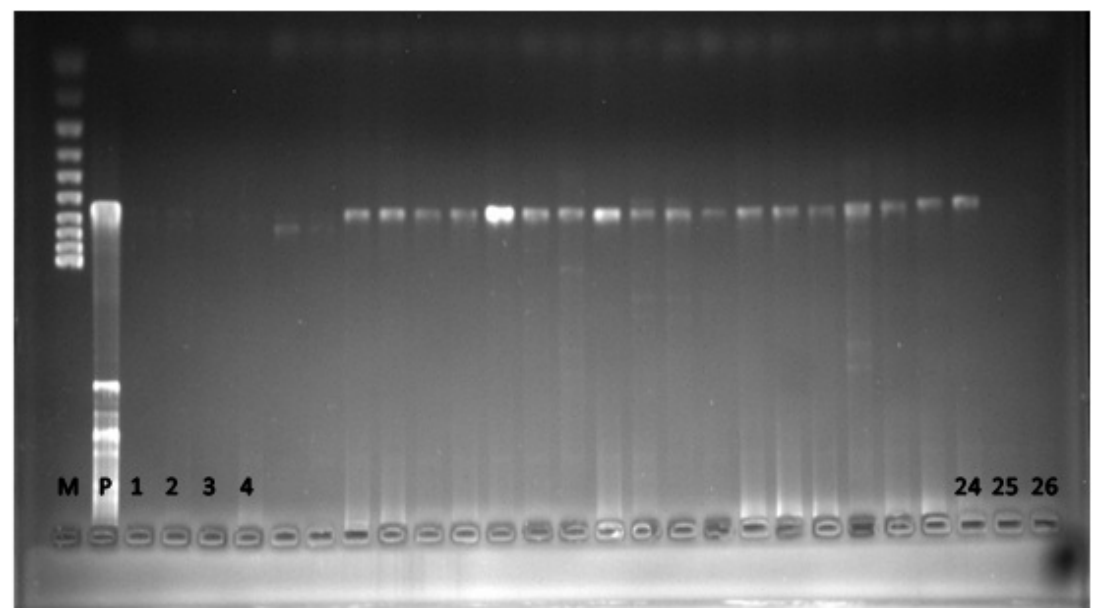

Fig. 4 PCR analysis of T0 transgenic plants with the 680 bp SINA primers. P: plasmid pANIC-5E; M: 100-bp marker; 1: water negative control; 2: Plant negative control; 3 to 6, 25, 26: non-transformed plants; 7 to 20: 'Isly' transgenic plants; 21 to 24: 'Amria' transgenic plants

Table 2 Experimental results for plantlet transformation in three durum wheat varieties under two induction media (IM1 and IM2)

\begin{tabular}{|c|c|c|c|c|c|}
\hline Variety & Induction medium & $\begin{array}{l}\text { Number of } \\
\text { regenerated plantlets }\end{array}$ & $\begin{array}{l}\text { Number of PPT } \\
\text { resistant plantlets }\end{array}$ & $\begin{array}{l}\text { Plantlets containing } \\
\text { SINA gene }\end{array}$ & $\begin{array}{l}\text { Transformation } \\
\text { efficiency }(\%)\end{array}$ \\
\hline \multirow{2}{*}{ 'Isly' } & IM1 & 103 & 67 & 18 & 4.50 \\
\hline & IM2 & 122 & 68 & 21 & 5.25 \\
\hline \multirow{2}{*}{ 'Amria' } & IM1 & 37 & 12 & 5 & 1.25 \\
\hline & IM2 & 55 & 5 & 0 & 0.00 \\
\hline \multirow{2}{*}{ 'Chaoui' } & IM1 & 42 & 4 & 0 & 0.00 \\
\hline & IM2 & 26 & 14 & 4 & 1.00 \\
\hline
\end{tabular}

Pellegrineschi et al. 2002). PCR analysis amplified the expected size for SINA gene $(680 \mathrm{pb})$ in transgenic plants and positive controls (pANIC-5E). Whereas, the negative controls (non-transformed plants, distilled water) and non-transformed T0 plants did not amplify the desired bands (Fig. 4). Transformation efficiencies were $9.75 \%, 1.25 \%$ and $1 \%$ for 'Isly', 'Amria' and 'Chaoui' varieties respectively. The 'Isly' variety has a significantly $(\mathrm{p}<0.05)$ higher transformation efficiency in both media compared to the other cultivars (Table 2).

The number of PPT resistant plantlets and transformation efficiency obtained were statistically unaffected by the additional $\mathrm{CuSO}_{4}$ in $\mathrm{IM} 2$ for three varieties.

\section{Discussion}

Several studies have shown that the use of $\mathrm{CuSO}_{4}$ in the basal medium has a stimulatory effect on callus induction, proliferation, somatic embryogenesis and regeneration of monocotyledonous plants such as barley (Dahleen 1995; Makowska et al. 2017; Wojnarowiez et al. 2002); rice (He and Deng-tang 2014; Sahrawat and Chand 1999) and wheat (Cai et al. 2014; Kumar et al. 2017; Purnhauser 1991; Tahiliani and Kothari 2004). Purnhauser (1991) and Cai et al. (2014) showed independently a positive correlation between the rate of wheat callus regeneration and concentration of $\mathrm{Cu} 2+$ in the culture medium. In the same study, Purnhauser reported that the regeneration of wheat callus is eight times higher on a medium containing a 100 times higher $\mathrm{CuSO}_{4}$ concentration than in the original MS medium. Two mechanisms have been proposed to explain this regeneration improvement: the inhibition of an ethylene precursor (Lidon et al. 1995) and the stimulation of $\mathrm{Cu}$-containing enzymes (Purnhauser and Gyulai 1993).

Our results on the 'Amria' and 'Isly' durum wheat varieties corroborate these earlier studies. The presence of micronutrient copper in the induction medium at a concentration of $1.25 \mathrm{mg} / \mathrm{L}(\sim 5 \mu \mathrm{M})$ increases the regeneration rate of wheat calli for these two varieties, although the enhancement is not statistically significant. The opposite effect occurred for the 'Chaoui' variety: copper supplement at the same concentration decreases the rate of callus induction and regeneration; again the impact remains not statistically significant.

In their study, Xiao-Min et al. (2012) tested three wheat 
genotypes 'CB037', 'Xinchun9', and 'Bobwhite'. Their results showed that $6.1 \mu \mathrm{M}$ of $\mathrm{CuSO}_{4}$ was toxic for mature embryos of all three wheat genotypes. Similarly, Khurana-Kaul et al. (2010) observed that the use of $5 \mu \mathrm{Mof} \mathrm{CuSO}_{4}$ inhibited shoot bud formation in monocotyledonous plants. This discrepancy in somatic embryogenesis response to increased $\mathrm{Cu} 2+$ can be explained by the fact that every species has its own nutrient requirement. Sahrawat and Chand (1999) and Ghaemi et al. (1994) postulated that the requirement of copper may be cultivar dependent and that the reaction to increased $\mathrm{Cu} 2+$ is genotype dependent. This might explain the variety dependent impact of copper on induction for durum wheat.

Allison et al. (2002) concluded in their study that transformation efficiency was consistently 1.3 to 4 times higher in Cu-treated callus cultures $(16.6 \%$ on average in twelve experiments) than in control $\mathrm{Cu}$-untreated ones $(8.4 \%$ on average in twelve experiments). Other studies reached a similar conclusion on the positive impact of $\mathrm{CuSO}_{4}$ on transformation efficiency in other monocots (Cho et al. 1998; Ishida et al. 2003).

Our investigation, which is the first one of its kind studying the effect of copper supplementation on transformation of mature wheat embryos using biolistic method, concluded that copper supplement at a concentration up to $5 \mu \mathrm{M}$ does not have much impact on callus induction, regeneration and transformation efficiency. The disparity of results reported in the literature could be explained by the difference in the transformation method and the nature of the starting explant.

In our study, the significant difference in transformation efficiency reflects the effect of genotype. The 'Isly' variety proved to be the most responsive to biolistic transformation using mature embryos. The rate of transformation efficiency of $9,75 \%$ is far superior to the typical range of 0.1 to $2.5 \%$ reported for mature and immature wheat embryos in other publications (Greer et al. 2009; Kasirajan et al. 2013; Quin et al. 2014; Rasco-Gaunt et al. 2003; Vendruscolo et al. 2007). A few studies have, however, reported higher efficiencies (Cai et al. 2014; Patnaik and Khurana 2003).

Furthermore, our observations indicate that there was no parallelism between regeneration capacity and transformation frequencies. For 'Amria' and 'Chaoui' varieties, we did not obtain any transgenic plants from the media recording the highest number of regenerated plantlets (Table 2). This supports similar results showing that the variability in transformation is more correlated to the genotypic and physiological status of the donor plants than to the efficiency of the biolistic procedure or the medium composition (Iser et al. 1999; Miroshnichenko et al. 2011; Rasco-Gaunt 2001; Ye et al. 2001). This finding confirms the works of Galovic et al.
(2010) and Ekom et al. (2014) on the bombardment of wheat embryos. They observed that varieties with the highest induction and regeneration capacities exhibited the lowest transformation efficiency.

\section{Conclusion}

In the present study, we have been able to successfully introduce SINA gene via particle bombardment into Moroccan durum wheat varieties. Results obtained show that the response to $\mathrm{CuSO}_{4}$ supplementation in the induction medium is genotype dependent and did not confirm the suggestion made by previous studies that additional copper supplementation enhances transformation efficiency. The impact of copper on transformation efficiency may depend on genotype, transformation method and type of explant.

Furthermore, the present investigation concludes as many earlier reports that transformation efficiency is highly genotype dependent. The 'Isly' variety gave very promising results, suggesting that it could be used in the future for further genetic transformation experiments in wheat. The high transformation efficiency obtained using mature embryos will facilitate studies on functional genomics and crop improvement. Since the transgenic plants developed in this study contained the SINA gene, further analysis for tolerance to water and salt in subsequent generations will be studied.

\section{Acknowledgements}

The authors would like to thank the International Centre for Genetic Engineering and Biotechnology (ICGEB) for generous funding.

\section{References}

Allison H, Feng X, Fry JE, Hu T, Lu F, Radionenko M (2002) Efficiency agrobacterium-mediated wheat transformation method

Cai L, Sun DF, Sun GL (2014) Optimization of a biolistic transformation system for transfer of antifreeze gene $\mathrm{KN} 2$ and the bar herbicide resistance gene in common wheat. Genet $\mathrm{Mol}$ Res 13(2):3474-3485

Cho MJ Jiang W, Lemaux PG (1998) Transformation of recalcitrant barley cultivars through improvement of regenerability and decreased albinism. Plant Sci 138(2):229-244.

Dahleen LS (1995) Improved plant regeneration from barley 
cultures by increased copper levels. Plant Cell Tiss Organ Cult 43:267-269

Ekom D, Udupa SM, Benchekroun MN, Ennaji MM, Abdelwahd R, Iraqi D (2014) Immature Embryo-Derived of Two Bread Wheat (Triticum aestivum L.) Varieties Transformation Using Particle Bombardment Method. Annu. Res. Rev. Biol 4:39043914

Fróna D, Szenderák J, Harangi-Rákos M (2019) The Challenge of Feeding the World Sustainability 11(20):5816

Galovic V, Rausch T, Grsic-Rausch S (2010) Mature embryoderived wheat transformation with major stress-modulated antioxidant target gene. Arch Biological Sci 62:539- 546

Ghaemi, M, Sarrafi A, Alibert, G(1994) The effects of silver nitrate, colchicines, cupric sulphate and genotype on the production of embryoids from anthers of tetraploid wheat (Triticum turgidum). Plant Cell Tiss Organ Cult 36:355-359

Greer MS, Kovalchuk I, Eudes F (2009) Ammonium nitrate improves direct somatic embryogenesis and biolistic transformation of Triticum aestivum. New Biotechnol 26:44-52

Hardwood WA (2012) Advances and remaining challenges in the transformation of barley and wheat. J. Exp. Bot 63:1791-1798

He S, Deng-tang Z (2014) Effects of $\mathrm{CuSO}_{4}$ and Uniconazole on Mature Embryo Culture in Japonica Rice, J. Northeast Agric. Univ (English Edition) 21(2):12-18

Iraqi D, Hakam N, Labhilili M (2005) Transformation génétique des embryons immatures du blé tendre (Triticum aestivum) et du blé dur (Triticum durum). Al Awamia Moroccan Journal of Agricultural Research 115:3-16 (in French with an abstract in English)

Iser M, Fettig S, Scheyhing F, Viertel K, Hess D (1999) Genotypedependent stable genetic transformation in german spring wheat varieties selected for high regeneration potential. J Plant Physiol 154:509-516

Ishida Y, Saito H, Hiei Y, Komari T (2003) Improved protocol for transformation of maize (Zea mays L.) mediated by Agrobacterium tumefaciens. Plant Biotech 20:57-66

Kasirajan L, Boomiraj K, Bansal KC (2013) Optimization of genetic transformation protocol mediated by biolistic method in some elite genotypes of wheat (Triticum aestivum L.). Afr j biotechnol 12(6):531-538

Khurana-Kaul V, Kachhwaha S, Kothari SL (2010) Direct shoot regeneration from leaf explants of Jatropha curcas in response to thidiazuron and high copper contents in the medium. Biol Plant 54(2):369-372

Kumar R, Mamrutha HM, Kaur A et al (2017) Development of an efficient and reproducible regeneration system in wheat (Triticum aestivum L.). Physiol Mol Biol Plants 23:945-954

le Roux ML, Botha AM, van der Vyver C (2016) Somatic embryogenesis and cryopreservation of South African bread wheat (Triticum aestivum L.) genotypes. S Afr J Bot 106:78-88

Lidon FC, Barreiro MG, Henriques FS (1995) Interactions between biomass production and ethylene biosynthesis in copper treated rice. J. Plant Nut 18:1301-1314

Lolkema PC (1985) Copper resistance in higher plants. Ph.D.
Thesis, Free University Press.

Maddock SE (1985) Cell culture, somatic embryogenesis and plant regeneration in wheat, barley, oats, rye and triticale. In: Cereal Tissue and Cell Culture Edited by: Bright SWJ, Jones MGK. Martinus Nijhoff, Dordrecht, pp 131-174

Makowska K, Oleszczuk S, Zimny J (2017) The effect of copper on plant regeneration in barley microspore culture. Czech $\mathrm{J}$ Genet Plant Breed 53:17-22

Miroshnichenko DN, Poroshin GN, Dolgov SV (2011) Genetic transformation of wheat using mature seed tissues. Appl Biochem Micro 47:767-775

Murashige T, Skoog F (1962) A Revised Medium for Rapid Growth and Bio Assays with Tobacco. Tissue Cultures. Physiol Plant 15:473497

Ozgens M, Turet M, Ozcan S, Sanzak C (1996) Callus induction and plant regeneration from immature and mature embryos of winter durum wheat genotypes. Plant Breed 115:455-458

Ozias-Akins P, Vasil IK (1983) Callus induction and growth from the mature embryos. Protoplasma 115:104-113

Parmar SS, Sainger M, Chaudhary D, Jaiwal PK (2012) Plant regeneration from mature embryo of commercial Indian bread wheat (Triticum aestivum L.) cultivars. Physiol Mol Biol Plants 18:177-183

Pastori GM, Wilkinson MD, Steele SH, Sparks CA, Jones HD, Parry MAJ (2001) Age dependent transformation frequency in elite wheat varieties. J Exp Bot 52:857- 863

Patnaik D, Khurana P (2003) Genetic Transformation of Indian Bread (T. aestivum) and Pasta (T. durum) Wheat by Particle Bombardment of Mature Embryo-Derived Calli. BMC Plant Biol 3:1-11

Pellegrineschi A, Noguera LM, Skovmand B, Brito RM, Velazquez L, Salgado MM, Hernandez R, Warburton M, Hoisington D (2002) Identification of highly transformable wheat genotypes for mass production of fertile transgenic plants. Genome 45:421-430

Pukhalskii VA, Smirnov SP, Korostyleva TV et al (1996) Genetic Transformation of Wheat Triticum aestivum L. via Agrobacterium tumefaciens, Russ J Genet 32:1202-1206

Purnhauser L, Gyulai G (1993) Effect of copper on shoot and root regeneration in wheat, triticale, rape and tobacco tissue cultures. Plant Cell Tiss Organ Cult 35:131-139

Purnhauser L (1991) Stimulation of shoot and root regeneration in wheat (Triticum aestivum) callus cultures by copper. Cereal Res Commun 19:419-423

Qin JB, Wang Y, Zhu CQ (2014) Biolistic transformation of wheat using the HMW-GS 1Dx5 gene without selectable markers. Genet Mol Res 13(2):4361-4371

Rasco-Gaunt S, Liu D, Li CP, Doherty A, Hagemann K, Riley A, Thompson T, Brunkun C, Mitchell M, Lowe K, Krebbers E, Lazzeri P, Jayne S, Rice D (2003) Characterization of the expression of a novel constitutive maize promoter in transgenic wheat and maize. Plant Cell Rep 21:569-576

Rasco-Gaunt S, Riley A, Cannell M, Barcelo P, Lazzeri PA (2001) Procedures allowing the transformation of a range of european elite wheat (Triticum aestivum L.) varieties via particle bom- 
bardment. J Exp Bot 52:865-874

Redha A, Talaat A (2008) Improvement of green plant regeneration by manipulation of anther culture induction medium of hexaploid wheat. Plant Cell Tiss Organ Cult 92:141-146

Sahrawat AK, Chand S (1999) Stimulatory effect of copper on plant regeneration in indica rice (Oryza sativa L.). J Plant Physiol 154(4):517-522

Shewry PR, Jones HD (2005) Transgenic wheat: where do we stand after the first 12 years? Ann Appl Biol 147:1-14

Sparks CA, Doherty A, Jones H (2014) Genetic transformation of wheat via Agrobacterium-mediated DNA delivery. In: Henry RJ, Furtado A (eds) Cereal genomics: methods and protocols. Series Methods in Molecular Biology, vol 1099. Springer, New York, pp 235-250

Tahiliani S, Kothari SL (2004) Increased copper content of the medium improves plant regeneration from immature embryo derived callus of wheat (Triticum aestivum). J Plant Biochem Biotech 13:85-88

Tao LL, Yin GX, Du LP, Shi ZY (2011) Improvement of plant regeneration from immature embryos of wheat infected by Agrobacterium tumefaciens. Agr Sci China 10:317-326

Udupa SM, Weigand F, Saxena MC, Kahl G (1998) Genotyping with RAPD and microsatellite makers resolves pathotype diversity in the ascochyta blight pathogen of chickpea. Theor Appl Genet 97:299-307

Vasil IK (2005) The story of transgenic cereals: the challenge, the debate, and the solution a historical perspective. In Vitro Cell
Dev Biol Plant 41:577-583

Vendruscolo ECG, Schuster I, Negra ES, Scapim C (2008) Callus induction and plant regeneration by Brazilian new elite wheat genotypes. Crop Breed Appl Biotechnol 8:195-201

Vendruscolo ECG, Schuster I, Pileggi M, Scapim CA, Molinari HBC, Marur CJ, Vieira LGE (2007) Stress-induced synthesis of proline confers tolerance to water deficit in transgenic wheat. J Plant Physiol 164:1367-1376

Wojnarowiez G, Jacquard C, Devaux P, Sangwan RS, Clement C (2002) Influence of copper sulfate on anther culture in barley (Hordeum vulgare L.). Plant Sci 162:843-847

Wu H, Sparks C, Amoah B et al (2003) Factors Influencing Successful Agrobacterium-Mediated Genetic Transformation of Wheat. Plant Cell Rep 21:659-668

Xia L, Ma Y, He Y, Jones HD (2012) GM wheat development in China: current status and challenges to commercialization. J Exp Bot 63(5):1785-1790

Xiao-Min B, Li-Pu D, Hui-Jun X, Xing-Guo X (2011) Effects of $\mathrm{CuSO}_{4}$ and Iron Source on the Tissue Culture of Wheat. J Plant Genet Resour 12(6):975-981

Ye XG, Xu HJ, Du LP, Xin ZY (2001) Study on the factors influencing the efficiency of wheat transformation. Sci Agri Sinica 34:128-132

Ziolkowski MJ (2007) Advancements in biolistics and applications for agriculturally significant crops. Microbiol. Mol. Genet 3:34-39 